British \& Irish Botany 2(4): 266-284, 2020

\title{
Hybrids in Juncus section Juncotypus, with a description of $J$. x lancastriensis (Juncaceae)
}

\author{
Clive A. Stace \\ Appletree House, Larters Lane, Middlewood Green, Suffolk IP14 5HB
}

\section{Corresponding author: cstace@btinternet.com}

This pdf constitutes the Version of Record published on $7^{\text {th }}$ December 2020

\begin{abstract}
The differences between the five native species of Juncus section Juncotypus that occur in the British Isles are summarised, and the occurrence of five hybrids surveyed. The diagnostic morphological and anatomical details of the hybrids are presented, with emphasis on the endemic $J$. balticus $x J$. inflexus, which is described as J. x lancastriensis Stace and of which two nothovars are distinguished.
\end{abstract}

Keywords: Juncus inflexus, Juncus balticus, Juncus effusus, Juncus conglomeratus, Juncus filiformis, stem anatomy, Lancashire coast.

\section{Introduction}

The five native species of Juncus section Juncotypus Dumort. (subgenus Genuini Buchenau) in the British Isles are well exemplified by the commonest species of the genus, J .effusus L. (Fig. 1), which by the year 2000 had been recorded from $97 \%$ of the approximately 3859 hectads (10 x $10 \mathrm{~km}$ squares) (Preston et al., 2002). The other species are J. conglomeratus L. (Fig. 2), J. inflexus L., J. balticus Willd. and J. filiformis L. (all shown in Fig. 3). These five differ from all other British species (in nine sections) in that their leaves, apart from the lowest inflorescence bract, are represented by brown sheaths (cataphylls) at the base of the stems. Sometimes in $J$. filiformis a single cataphyll has a short green blade. Species in all other sections have green leaves borne on and/or at the base of the stems. Section Juncotypus is perennial and rhizomatous, the rhizomes having long internodes which give rise to scattered stems in J. balticus and J. filiformis, or shorter internodes with many branches producing a clumped growth-habit in the other three species (Fig. 4). The stems are erect and cylindrical, and carry a single, usually rather compact inflorescence that is technically apical, but which appears to be lateral because it is displaced laterally by the lowest bract, which is also cylindrical and is effectively a continuation of the stem beyond the inflorescence (and has the same anatomy).

The five species are easily distinguishable (Stace, 2019), and their characters will not be repeated here, except that J. effusus and J. conglomeratus are frequently confused, partly because some Floras and identification guides rely solely on the degree of stem ridging to separate them. These characters are usually but not totally reliable, and counting ridges on a cylindrical stem is not easy. A clear difference is that the main (lowest) bract is somewhat opened out at its base in $\mathrm{J}$. conglomeratus (Fig. 2), forming a point of weakness so that in autumn the bract often characteristically hinges over backwards or frontwards at that point (Fig. 2), whereas in J. effusus the bract is subcylindrical and scarcely opened out at its base, so that it 
usually remains stiffly erect into winter or is bent irregularly by the winds. Both species exist as variants with either compact or diffuse inflorescences (e.g. Fig. 1; Stace, 2019). In the fresh state they are distinguishable with experience by the dull green stems with usually $<30$ longitudinal ridges counted just below the inflorescence (see below) in J. conglomeratus, as opposed to the bright green smooth stems in J. effusus. In the latter species, as the stems dry out, ridges (usually $>30$ in number, see below, and less prominent/sharp) appear. Other estimates of this feature can be obtained by cutting stem-sections and counting the major vascular bundles, or counting the subepidermal girders (see below). These three measures give slightly different sets of figures. The main bract of $J$. conglomeratus is also shorter, and occupies a smaller proportion of the total stem/bract height, than in $J$. effusus. Where the two species co-exist $J$. conglomeratus dies down more quickly in autumn, the main bract quickly browning, then bending over and often breaking off.

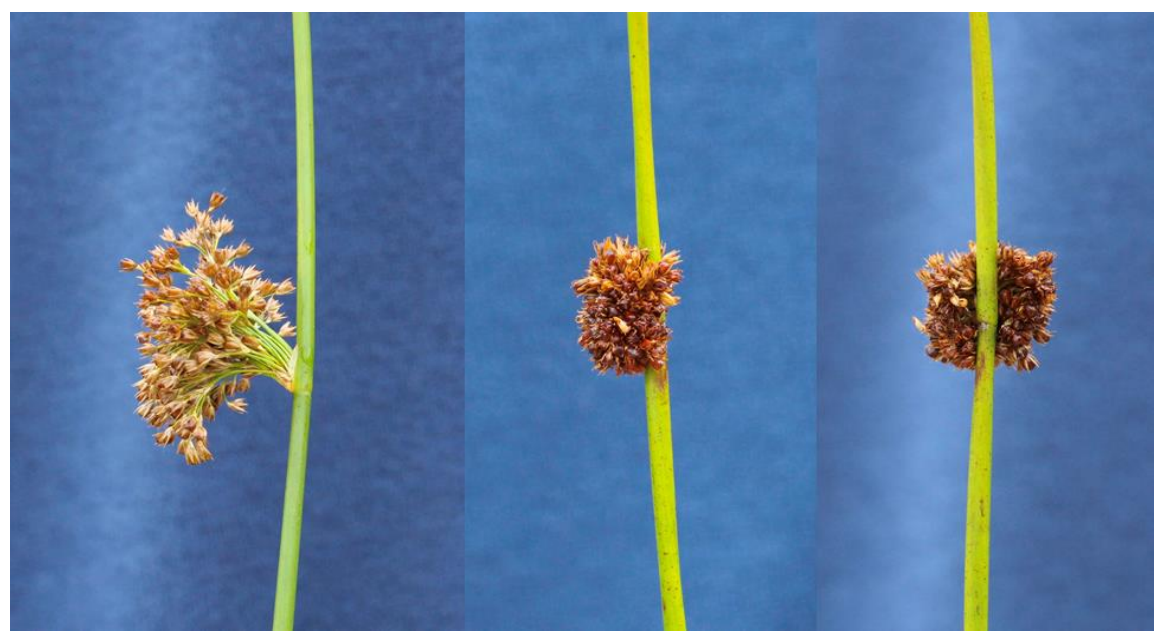

Figure 1. Inflorescences of Juncus effusus var. effusus (left), J. effusus var. subglomeratus DC (var. compactus Lej \& Coutois) lateral view (centre) and abaxial view (right). All photos by Richard Stace

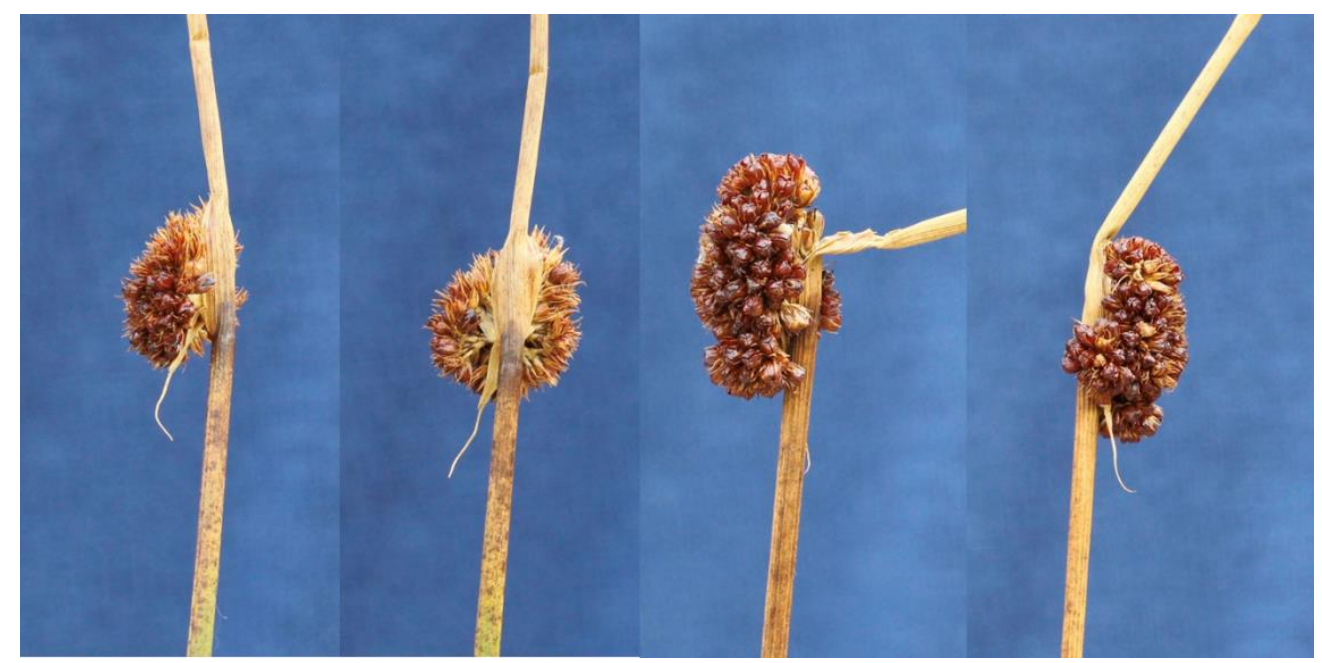

Figure 2. Inflorescences of Juncus congomeratus, Lateral view (left), abaxial view (centre left), with bract bend backwards (centre right), and with bract bent forwards (right). All photos by Richard Stace 


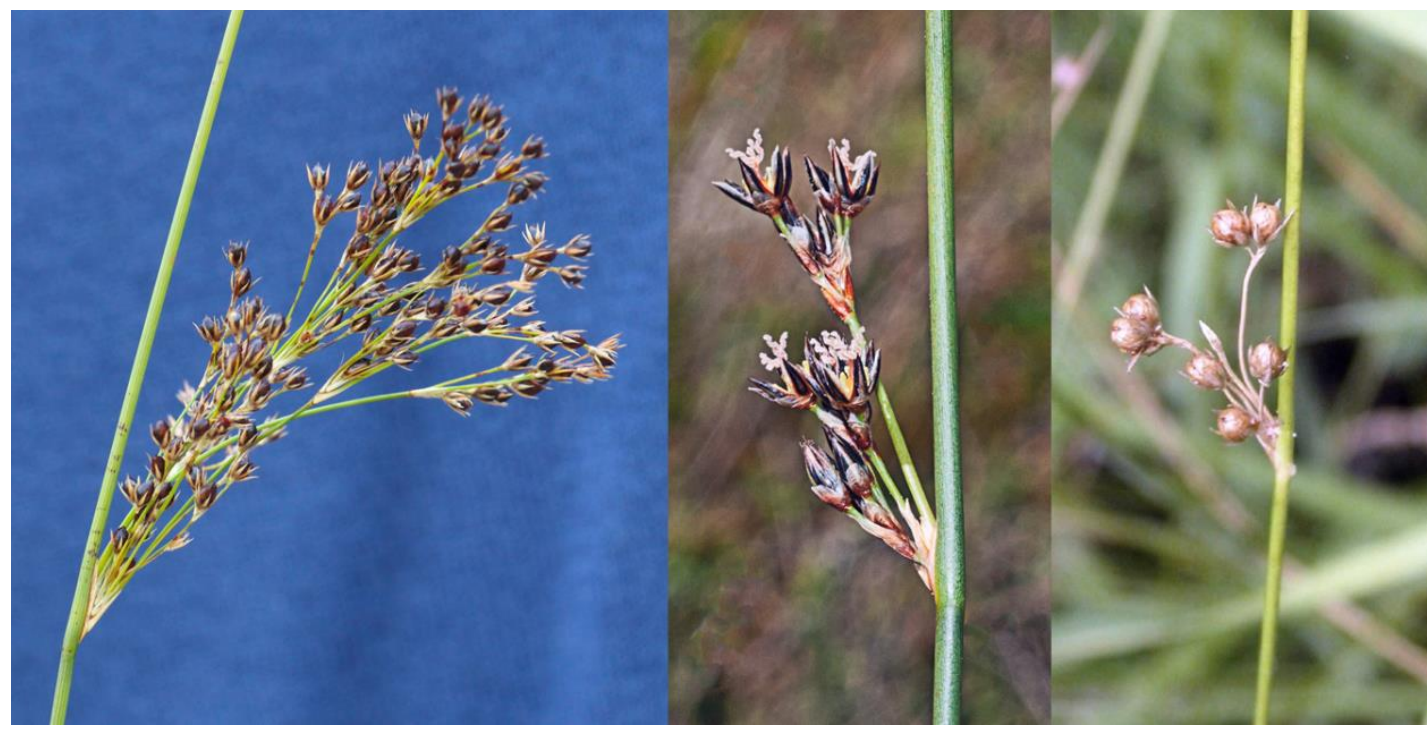

Figure 3. Inflorescences of Juncus inflexus (left, Richard Stace), Juncus balticus (centre, Phil Smith) and Juncus filiformis (right, Mike Wilcox)
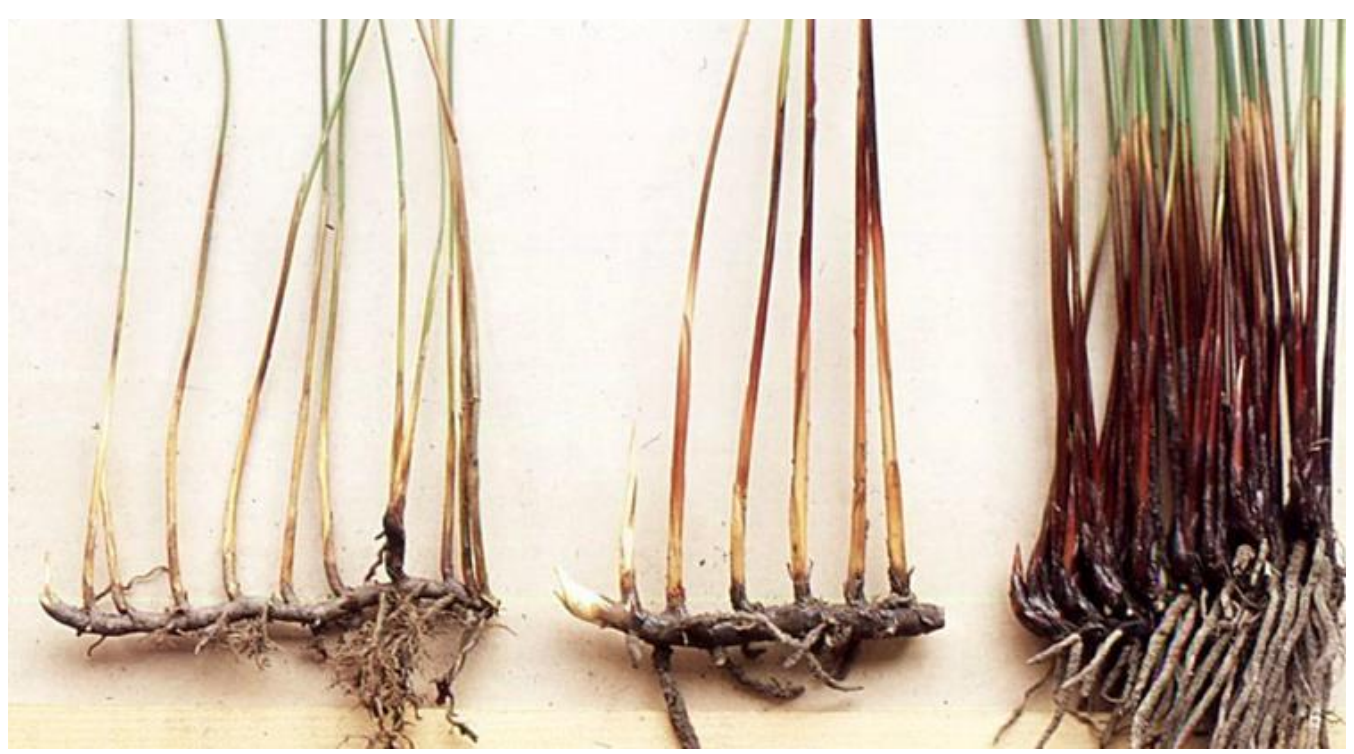

Figure 4. Rhizomes of Juncus balticus (left), J. inflexus (right) and their hybrid (centre)

Stem anatomy provides important features separating all five species, best displayed by cutting thin transverse sections with a razor-blade (Stace, 1970b). Working inwards from the epidermis there are three main zones: an outer palisade zone of living chloroplast-containing cells (chlorenchyma); a zone of parenchyma cells in which many vascular bundles are embedded and are surrounded or capped by a sclerenchyma sheath; and a central pith. Abutting on to the epidermis in the chlorenchyma, in all the species apart from J. balticus, are longitudinal subepidermal sclerenchyma girders, which are very conspicuous in transverse section. The larger ones sometimes join up with the sclerenchyma bundle-sheaths of some of the vascular bundles. In J. conglomeratus and J. inflexus particularly, their presence 
coincides with the position of the external ridges. The four main distinguishing anatomical features of the stems are summarized below and in Fig. 5 .

\section{J. effusus (Fig. 5, top left)}

Epidermal cells all \pm same size

Subepidermal sclerenchyma girders 36-62 (mostly 40-55) in number (Chater, pers. comm.; Wilcox, 2010), linear to narrowly triangular in section, often stretching across chlorenchyma zone and joining up with some sclerenchyma bundle-sheaths; not causing epidermis to bulge externally to form stem-ridges in fresh state Pith longitudinally continuous, dense

Pith-cells strongly stellate

\section{J. conglomeratus (Fig. 5, top right)}

Epidermal cells all \pm same size, or sometimes slightly enlarged over girders Subepidermal sclerenchyma girders 12-29 (mostly 15-25) in number (Chater, pers. comm.; Wilcox, 2010), more or less triangular in section, sometimes stretching across chlorenchyma zone and joining up with sclerenchyma bundle-sheaths; causing epidermis to bulge externally to form stem-ridges

Pith longitudinally continuous, usually less dense than in J. effusus Pith-cells strongly stellate

\section{J. inflexus (Fig. 5, centre left and right)}

Epidermal cells markedly enlarged over girders, accentuating stem ridging Subepidermal sclerenchyma girders mostly 10-18 in number (Wilcox, 2010), triangular to broadly triangular in section, often stretching across chlorenchyma zone and joining up with some sclerenchyma bundle-sheaths; causing epidermis to bulge externally to form strong stem-ridges

Pith regularly interrupted longitudinally, forming numerous and close septa across pith cavity

Pith-cells strongly stellate

\section{J. filiformis}

Epidermal cells all \pm same size

Subepidermal sclerenchyma girders mostly c. 15-22 in number, compact, markedly wider in tangential than radial plane, not stretching across chlorenchyma zone and joining up with sclerenchyma bundle-sheaths; not causing epidermis to bulge externally to form strong stem-ridges

Pith longitudinally \pm continuous, not dense

Pith-cells angular or balloon-shaped, not stellate

\section{J. balticus (Fig. 5, bottom left and right)}

Epidermal cells all same size

Subepidermal sclerenchyma girders absent

Pith longitudinally \pm continuous, not dense

Pith-cells angular or balloon-shaped, not stellate 


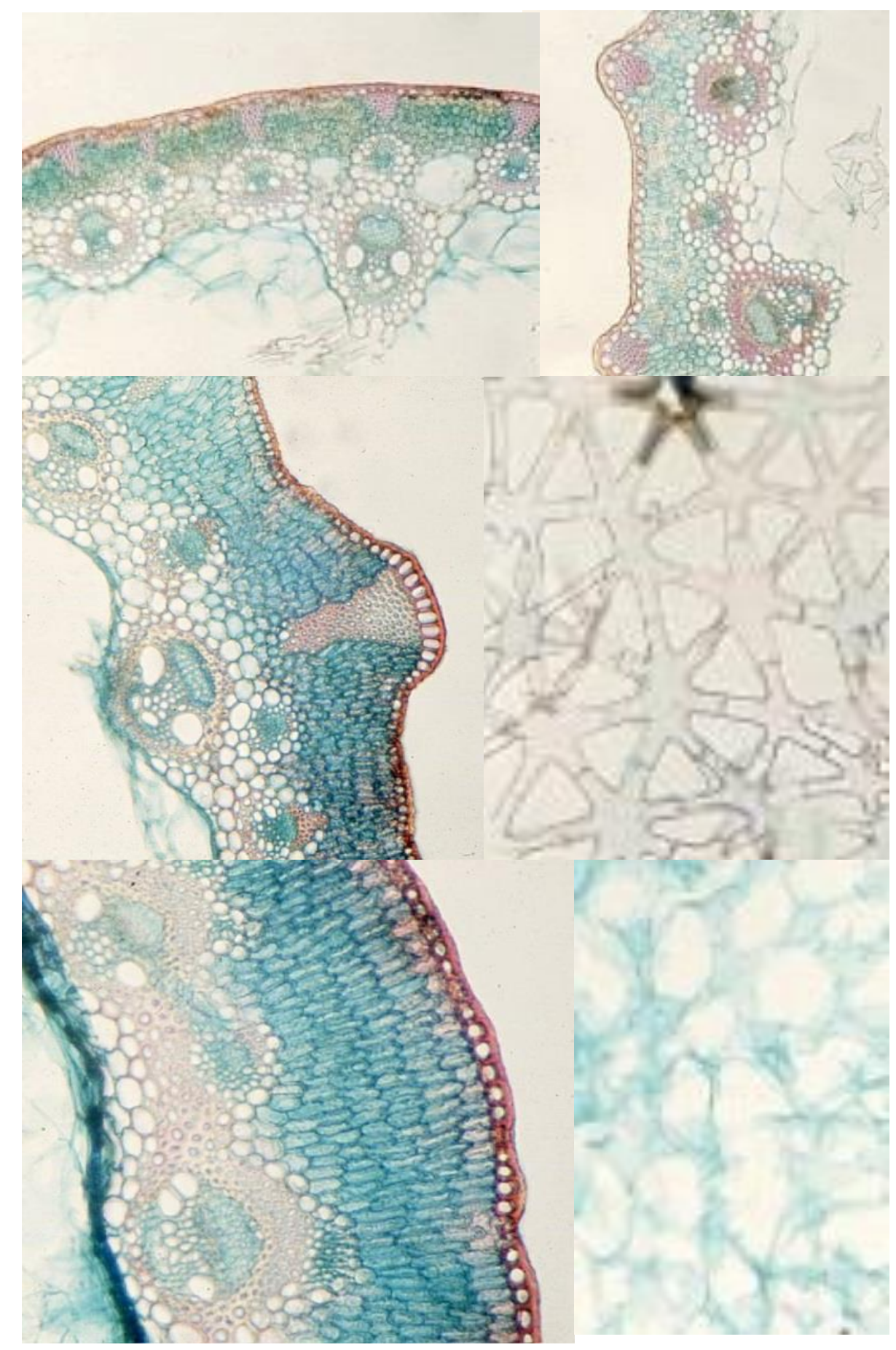

Figure 5. Stem anatomy of Juncus taxa. Top left: $J$. effusus, showing slender subepidermal sclerenchyma girders and non-enlarged epidermal cells; Top right: J. conglomeratus, showing triangular subepidermal sclerenchyma girders and non-enlarged epidermal cells; Centre left: J. inflexus, showing large subepidermal sclerenchyma girders with overlying enlarged epidermal cells; Centre right: long-armed stellate pith-cells of J. inflexus, Bottom left: J. balticus, showing absence of subepidermal sclerenchyma girders and non-enlarged epidermal cells; Bottom right: balloon-shaped pith-cells of $\mathrm{J}$. balticus 


\section{Occurrence of hybrids in section Juncotypus}

Four hybrids involving four of the five species occur in Britain, a further one in Scandinavia, and there is a sixth dubious combination (Stace 1970a, 1970b, 1972, 1975a, 1975b; Stace et al., 2015).

Juncus effusus $\mathrm{x} J$. inflexus ( $=\mathrm{J}$. $\mathrm{x}$ diffusus Hoppe) was described in 1819 and has been known in this country since at least 1843, originally being treated as a full species and not fully accepted as a hybrid until the $1880 \mathrm{~s}$. Although it is easily recognized (Figs. $6 \& 7$ ) after practice by intermediacy of inflorescence form and by shape and size of sclerenchyma girders, in the past it has often been misidentified, usually mistaken for sterile specimens of $J$. inflexus (which are not rare), and this still happens. Clifford (1959) discussed this problem in some detail. It is well scattered but not common throughout the British Isles as far north as the northern limit of J. inflexus in central Scotland. Early accounts noted the small capsules with few seeds, and several considered it to be a sterile hybrid. The seeds, however, although relatively few, are not sterile and are easily germinated. I have raised a vigorous $F_{2}$ generation which showed segregation of the parental characters, producing some plants much closer to the parental species. Moreover, in central France (Puy de Dôme) in 1969 I discovered many plants in an obviously segregating hybrid swarm; to my knowledge such a population has not been reported from Britain, where the hybrid usually occurs as isolated individuals in mixed populations. In Anglesey, however, in 1970 I found several plants of this hybrid that showed two distinct variants, one with bright green stems, the other with grey-green stems, but, in those situations where several plants have been found, studies sufficient to determine whether they are all $F_{1}$ individuals or a segregating population have apparently not been made.

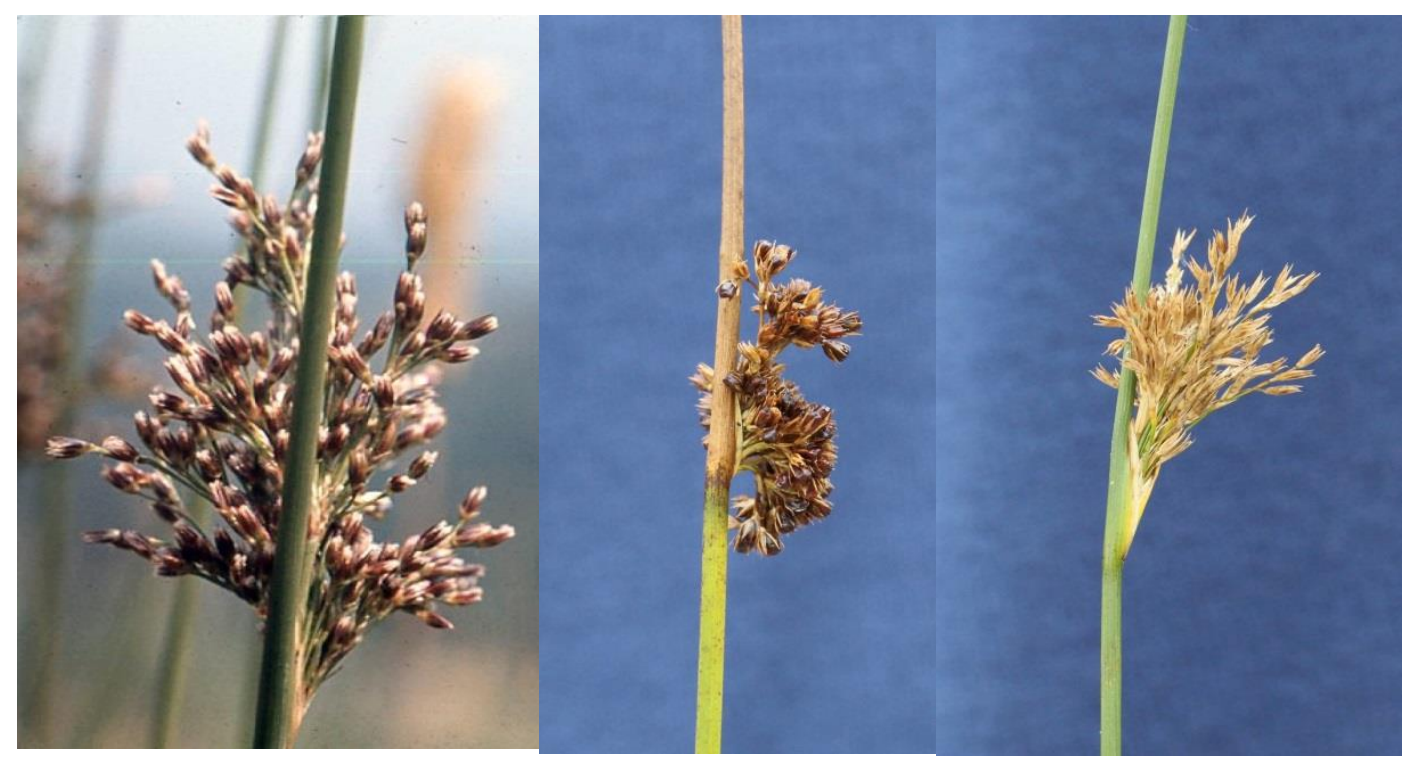

Figure 6. Inflorescences of Juncus $x$ diffusus (left), J. x kern-reichgeltii (centre, Richard Stace) and artificial J. conglomeratus $x$ J. inflexus (right, Richard Stace) 


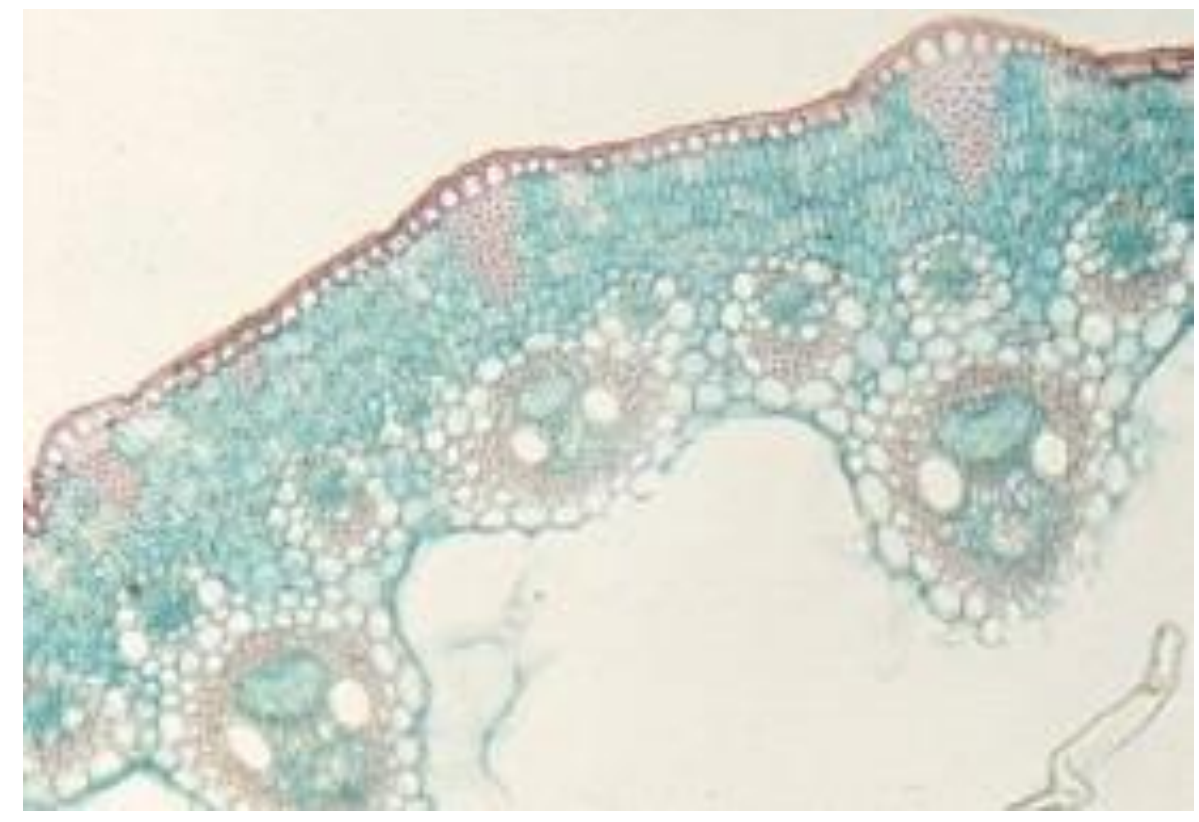

Figure 7. Stem section of Juncus $x$ diffusus, showing intermediate subepidermal sclerenchyma girders

Juncus conglomeratus $\mathrm{x} J$. effusus $(=\mathrm{J}$. $\mathrm{x}$ kern-reichgeltii Jansen \& Wacht. ex Reichg.) has a more chequered history (Fig. 6). It was not described validly until 1964, but there are scattered old British records going back over a century. However, determination was very uncertain and for long the existence of this hybrid in Britain was not accepted. I had seen no convincing examples up to 1971. Much of the evidence for the records was based on the supposed sterility of this hybrid, but sterility, of unknown cause, is common in plants of section Juncotypus (especially in $J$. inflexus), and the use of unreliable characters to separate the two parents which was prevalent in the mid-20 th century (see above) did not help identification. However, Agnew (1968) reported this hybrid from the uplands of Snowdonia, and in 1971 I visited his locality in Cwm Idwal, where it occurs in a contiguous zone between stands of the two parents. Using the reliable bract character, as well as ridge number and prominence, and stem/bract ratio, there can be no doubt that Agnew was correct. The plants, however, are highly (perhaps fully) fertile, as noted by Agnew, and since then this observation has been confirmed in other localities scattered across most of the British Isles (Wilcox, 2010). Moreover, the hybrid also occurs in lowland areas and is probably under-recorded due to continuing uncertainty of determination, which is best carried out in the field where both parents coexist. Probably its greater frequency in upland areas is due to the larger number of suitable habitats there. In 2019, in the fenland of the Weerribben in the Netherlands, lying at less than $10 \mathrm{~m}$ either side of sea-level, I found the hybrid and both parents to be exceptionally abundant over several hectares. British records from before 1968 not supported by vouchers, and any claiming sterility, should not be accepted. I have grown a very extensive $F_{2}$ population from Cwm Idwal seed, which completely bridged the characters of the two parents (Stace, 1975a, pp. 8283) and retained full fertility. A detailed analysis of wild populations was carried out by Wilcox (2010), who demonstrated extensive introgression in some mixed 
populations. Due to back-crossing the whole range of intermediates between the two parents is often exhibited.

Juncus conglomeratus $\mathrm{x} J$. inflexus ( $?=J$. $\mathrm{x}$ ruhmeri Asch. \& Graebn.) is accepted in several European countries but I know of no valid records for Britain. There are, however, unsubstantiated British records going back to the early part of the $20^{\text {th }}$ century, many under the name J. x leersii T. Marsson, but in $1968 \mathrm{~S}$. Snogerup examined the type of this name in Vienna $(\mathbf{W})$ and found it to be $J$. conglomeratus. The application of the binomial J. x ruhmeri of course rests upon confirmation of its identity as this hybrid. The type, collected by G.F. Ruhmer from "Brandenburg, Friedeberg, zwischen Wildenow und dem Busch", was in Berlin (B) but was destroyed in the Second World War, so we shall probably never know its true identity. A specimen in $\mathbf{W}$ collected in 1965 as J. x ruhmeri by H. Melzer from Südkärnten, near Bleiburg Railway Station, Austria, was examined by S. Snogerup in 1978 , and he confirmed its identity, saying on a label that the stem ridges are fewer and sharper than in J. x diffusus. But in 2017 M.P. Wilcox re-examined it (including stem sections) and concluded that it is $J$. x diffusus (Wilcox, 2017). Based on the number of stem ridges and sclerenchyma girders observed by me in these two hybrids and in the Melzer specimen, Wilcox's opinion prevails. In 2013/14 Wilcox obtained a few seeds from an artificial cross between the parents ( $J$. inflexus as female parent); four plants were raised from this and are still in cultivation (Wilcox, 2015). The existence of this hybrid in the wild anywhere is still sub judice, and certain identification would be difficult.

Juncus balticus $x J$. effusus ( $=J$. $x$ obotritorum Rothm.) has been recorded from the Baltic coast twice. The first record was from what is now Kaliningrad, where it was described in 1893 as J. x scalovicus Asch. \& Graebn. S. Snogerup, however, informed me (in litt.) that he examined the type and found it to be J. balticus $\mathrm{x} J$. filiformis, hence a synonym of $J$. $\mathrm{x}$ inundatus. The hybrid was later described from near Rostock in north-eastern Germany in 1965 as J. x obotritorum Rothm. Snogerup and I have both examined the type and agree that it is J. balticus $\mathrm{x} J$. effusus. The discovery of this hybrid by S. Taylor at Ainsdale, South Lancs, v.c. 59, England in 1933, and its subsequent history, naming and extinction, are detailed by Stace $(1972)$ and updated by Smith $(1984,2006)$ and Smith \& Lockwood $(2016)$. By 1966 the original patch in a wet dune-slack measured about $40 \times 20$ m (Fig. 8), but in $1967 / 68$ it was completely eradicated by the development of a holiday camp on the site. In 1966 and 1973 two other very small (no more than $1 \times 1 \mathrm{~m}$ ) patches were found by V. Gordon and E.F. Greenwood respectively about $9 \mathrm{~km}$ south of the original at Hightown, but these too were soon eradicated, the first by new houses before 1974, the second by erosion around 1978. Fortunately living pieces were taken from the 1933 and 1973 wild sites and these are now established in wet duneslacks in the Ainsdale National Nature Reserve. On the Continent the Rostock locality is still the only confirmed site. 


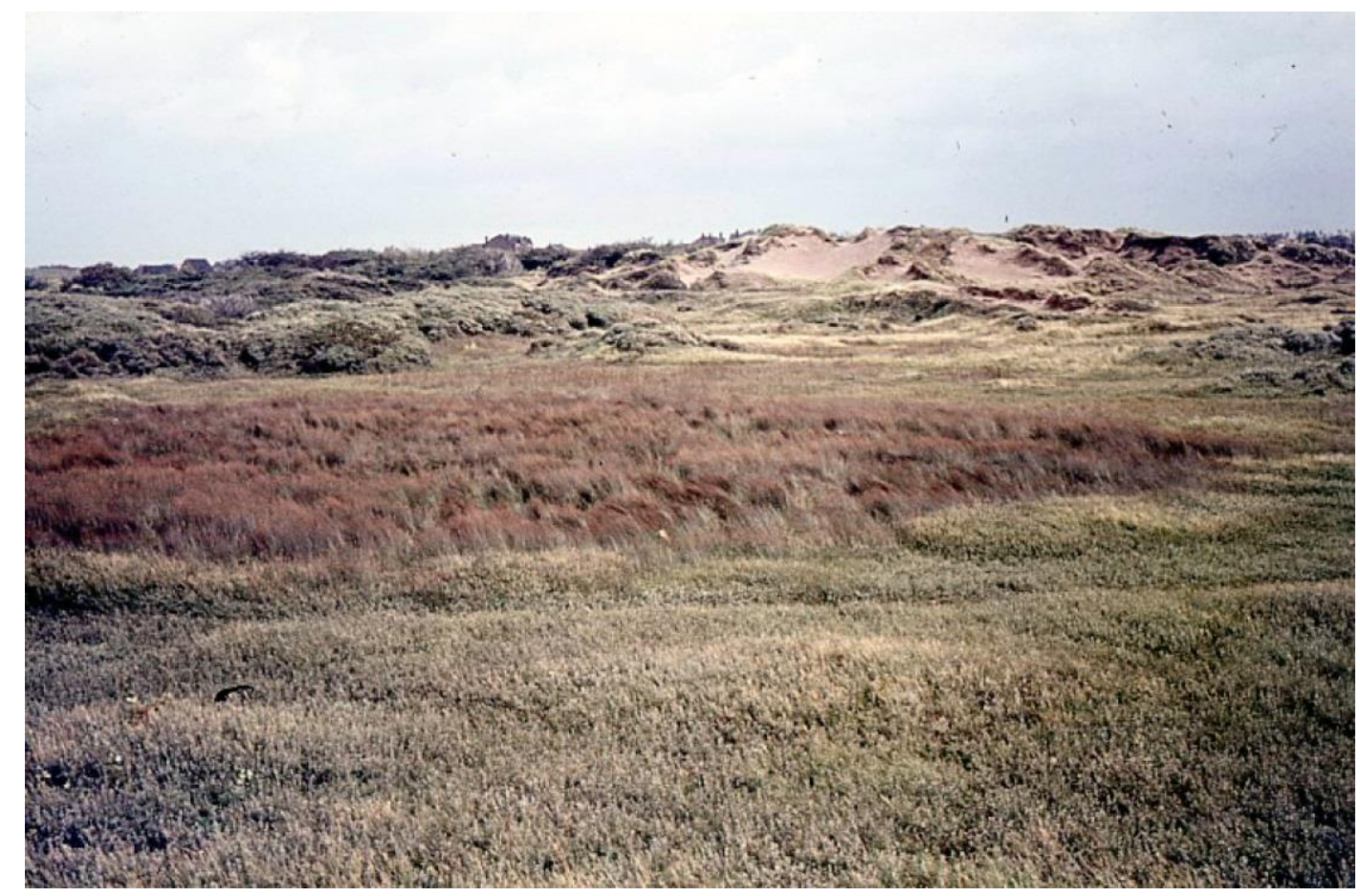

Figure 8. Original site of Juncus x obotritorum at Ainsdale, 1967

Juncus balticus $\mathrm{x}$ J. inflexus has never been found outside Lancashire; its discovery by D.E. Allen at Birkdale, only about $2 \mathrm{~km}$ north of the original J. balticus $\mathrm{x}$ J. effusus colony (Figs. $9 \& 10$ ) in 1951 and subsequent history and naming are again detailed by Stace (1972) and updated by Smith $(1984,2006)$ and Smith \& Lockwood (2016). A second colony was discovered independently by B. Blanchard about the same time about $4 \mathrm{~km}$ to the south of the first, in the Ainsdale N.N.R. near Freshfield (Fig. 11). This area of Lancashire (the Sefton coast, roughly between Crosby and Southport, South Lancs, v.c.59) is particularly rich in this section of Juncus, and supports the only English colonies of J. balticus itself (Stace, 1970a). A third colony of the hybrid was found by C.A. Stace in July 1966 outside this area, about $18 \mathrm{~km}$ further north, on the Fylde coast (between Lytham St Annes and Blackpool, West Lancs, v.c. 60), in the Lytham St Annes Local Nature Reserve, in an area where J. balticus was once known but no longer occurs (Fig. 12). All three of these colonies measured at least $10 \mathrm{~m}$ across in 1970, and were still thriving into the next decade (Smith 1984). However, Smith (2006) reported that the Freshfield site had been lost in the late 1980s due to sand-blow which, together with colonising scrub (mainly Salix repens, $S$. cinerea and Hippophae rhamnoides), is a constant threat to the dune-slacks. The two remaining colonies were still thriving in 2015 (Smith \& Lockwood, 2016), the Birkdale colony occupying $1260 \mathrm{~m}^{2}$ and the Fylde colony $398 \mathrm{~m}^{2}$. Material from the Freshfield and Fylde sites has been planted in other dune-slacks in the Ainsdale N.N.R., where they are now increasing. This paper provides a valid binomial for J. balticus $x$ J. inflexus.

Juncus balticus $\mathrm{x} J$. filiformis was named in 1839 as $J . \times$ inundatus Drejer. It is not known in Britain, where both species are quite rare and are not known to coexist, but there are many sites for it in northern Europe. 


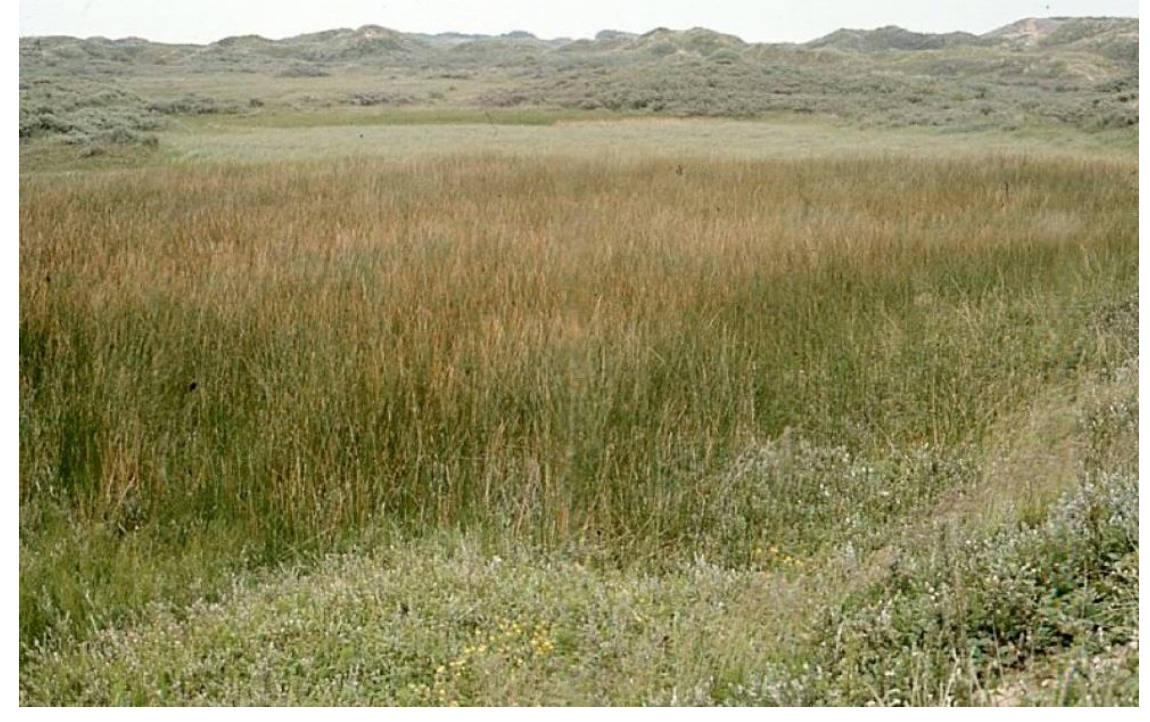

Figure 9. Birkdale site of Juncus x lancastriensis nothovar. lancastriensis, 1969

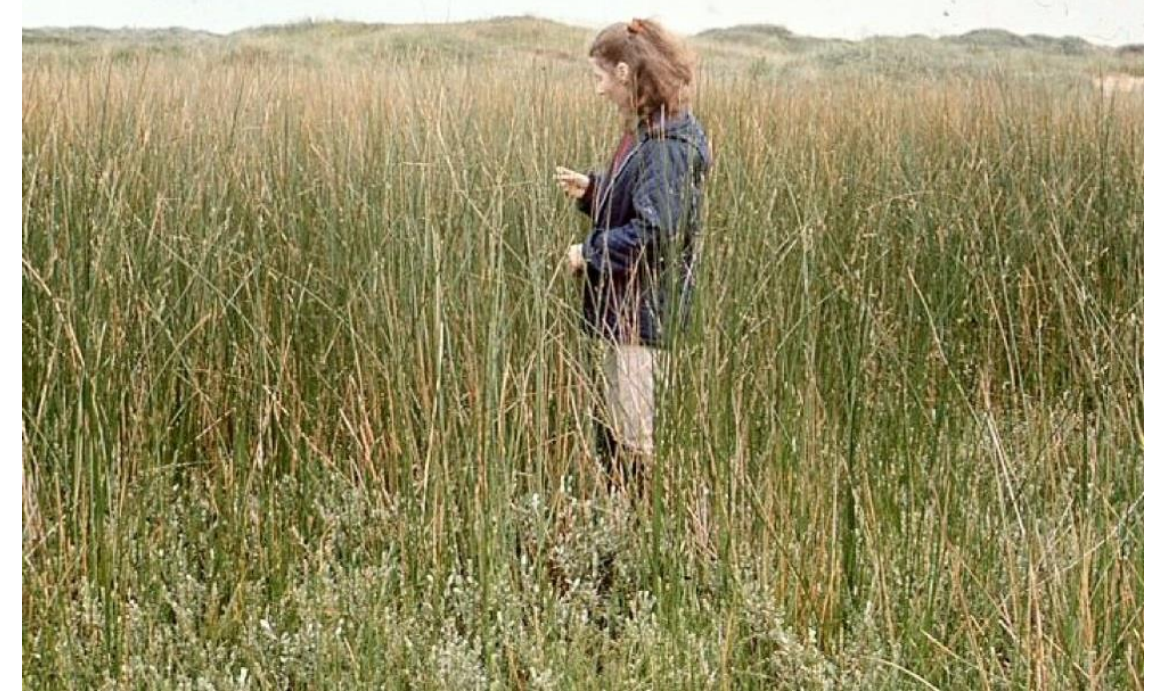

Figure. 10. Birkdale site of Juncus x lancastriensis nothovar. lancastriensis, 1969, with Pauline Moorhouse indicating stem height

\section{Characters of the hybrids}

A rule of thumb in identifying hybrids is that they are generally intermediate between their parents and sterile. Both these presumptions are true and untrue to varying degrees in these rushes. Some generalisations may be made:

- The hybrids between J. balticus, which has elongated rhizomes, and the compact species $J$. effusus and $J$. inflexus have rhizomes at least as elongated as those of $\mathrm{J}$. balticus.

- In hybrids between two species that both possess subepidermal sclerenchyma girders ( $J$. conglomeratus $\times$ J. effusus and J. effusus $\times$ J. inflexus), the size and number of girders is intermediate. But in crosses between a species without girders ( $\mathrm{J}$. balticus) and one with girders ( $\mathrm{J}$. effusus, J. inflexus or $\mathrm{J}$. filiformis) girders are completely absent. 


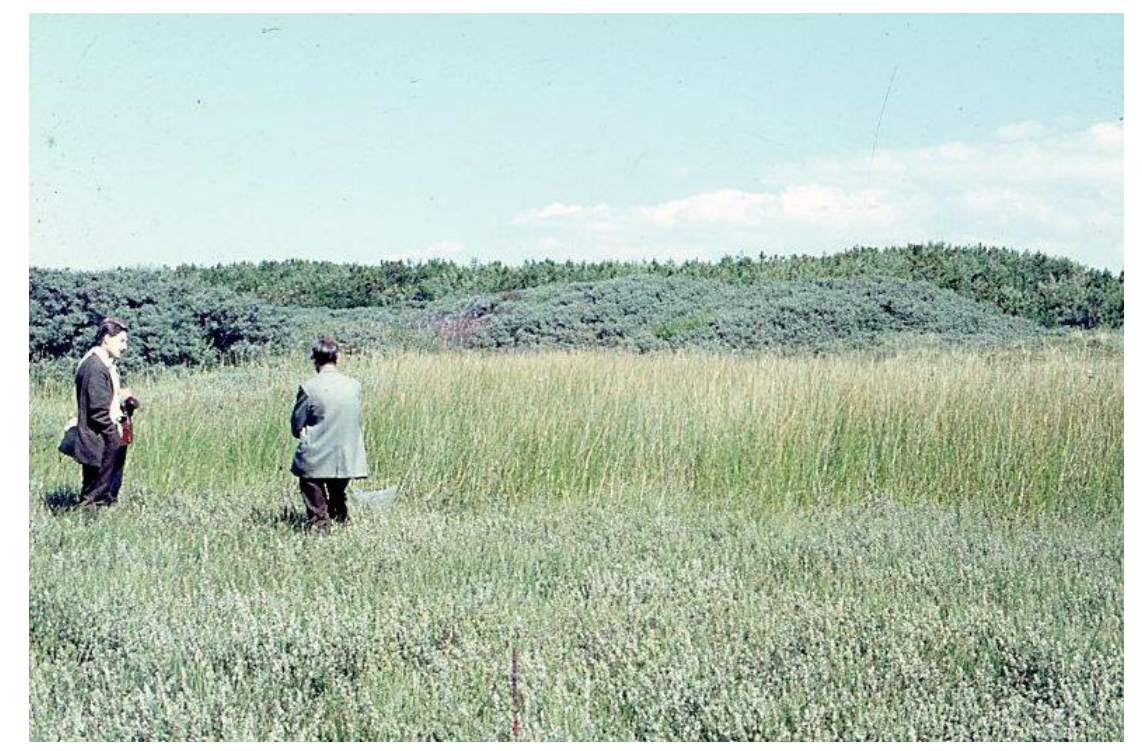

Figure 11. Freshfield site of Juncus $x$ lancastriensis nothovar. lancastriensis, 1968, now gone, with Eric Greenwood and John Tallis

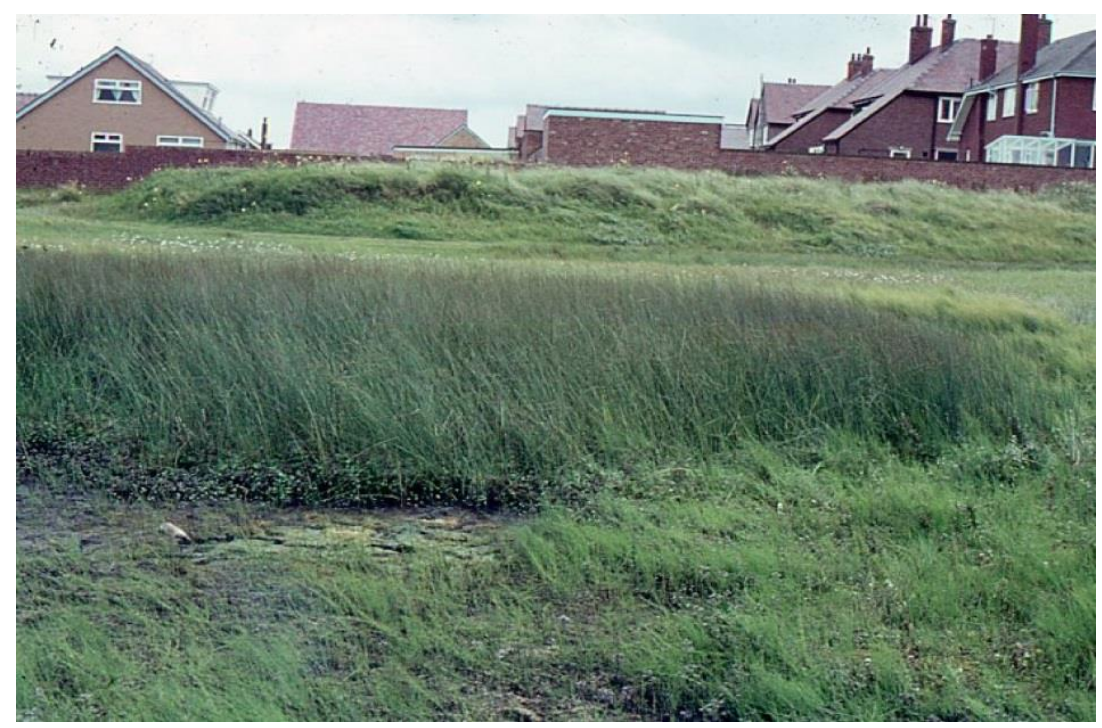

Figure 12. Lytham St. Anne's site of Juncus $x$ lancastriensis nothovar. fyldensis, 1969

- The enlarged epidermal cells over the girders evident in J. inflexus are sometimes apparent in its hybrid with J. effusus (Fig. 7), but are often conspicuous in its hybrid with J. balticus (Fig. 14), even though J. balticus and the hybrid have no subepidermal girders.

- J. inflexus alone has a septate (discontinuous) pith. In its hybrids with $J$. effusus and $J$. conglomeratus the pith is more or less continuous, but in the $J$. effusus hybrid it is less dense than in J. effusus itself and sometimes it shows irregular discontinuity. In its hybrid with $J$. balticus the pith is discontinuous in the Sefton hybrids (though much less regularly so than in J. inflexus) but continuous in the Fylde plants.

- In hybrids between J. balticus, which has angular or balloon-shaped pith-cells, and J. effusus or J. inflexus, which have stellate pith-cells with long arms, the 
pith-cells are intermediate, being stellate but with much shorter arms (Fig. 14).

- Fertility covers a broad scale. J. conglomeratus $x$ J. effusus is highly, perhaps fully, fertile; J. effusus $\mathrm{x} J$. inflexus and J. conglomeratus $\mathrm{x} J$. inflexus have a much reduced fertility; and the two hybrids of $J$. balticus are highly (though not completely) sterile. It is worth mentioning that in Juncus the pollen is dispersed in tetrads, and that in all the hybrids, even those highly sterile, the pollen appears perfectly normal and stainable. Moreover it germinates on and penetrates the stigma, but the pollen-tubes do not progress far (J.W. Grimes \& C.A. Stace, unpubl.).

As may be deduced from the above list, the most important characters identifying the hybrids involve stem anatomy rather than external morphology. The main diagnostic characters of five of the hybrids are as follows; J. balticus $\mathrm{x} J$. inflexus is covered in the next section.

\section{J. effusus $\times$ J. inflexus = J. $x$ diffusus (Figs. $6 \& 7$ )}

The inflorescence shape is slightly more like that of $J$. inflexus, with its mainly upswept branches, but the stem-pith is continuous, as in J. effusus, albeit usually less dense than in the latter. The other characters are more or less intermediate: the subepidermal sclerenchyma girders and therefore the external stem ridging are intermediate in number (mostly 30-42 according to Wilcox, 2010; c.18-45 according to Richards, 1962), size and shape; and the stems are neither bright green and glossy as in J. effusus nor glaucous as in J. inflexus. The characteristically enlarged epidermal cells overlying the girders of $J$. inflexus are sometimes apparent. Fertility is greatly reduced, but some seeds, which germinate readily, are usually produced.

\section{J. conglomeratus $\times$ J. effusus $=$ J. x kern-reichgeltii (Fig. 6)}

The hybrid displays intermediate characteristics in the degree of opening of the base of the main bract, in the relative lengths of bract and stem, and in the duller green stems with an intermediate number of ridges which are usually visible even in the young fresh state (not completely smooth as in fresh $J$. effusus). The number of ridges was stated as (30)35-42(55) by Wilcox (2010) and 30-40 by Chater (pers. comm). The degree of compactness of the inflorescence depends upon that of its $J$. effusus parent. The hybrid is highly (perhaps fully) fertile and often gives rise to populations displaying the total range of morphology, so that a precise number of stem-ridges cannot be indicated.

\section{J. conglomeratus $\times$ J. inflexus $=$ ? J. $x$ ruhmeri (Fig. 6)}

Comments here are based solely on the artificial hybrid raised by M.P. Wilcox, in which the stems and inflorescences resemble those of J. x diffusus, but the base of the bract is slightly opened out indicating the influence of $J$. conglomeratus. The stems are dark green in colour and the pith is continuous and dense. Fertility is very low but some full seeds are formed (probably a similar percentage to those in $J . x$ diffusus). The inflorescence branches are more erect than is usual in in J. $\mathrm{x}$ diffusus, without any spreading lower branches and, as might be expected, there are fewer (12-20) stem ridges. 
J. balticus $\times$ J. effusus $=$ J. $\times$ obotritorum (Fig. 13)

The hybrid resembles $J$. balticus more than its other parent. The inflorescence is very similar in shape to that of J. balticus, although often somewhat longer and more branched, the rhizomes are equal to it in degree of elongation, and subepidermal sclerenchyma girders and stem ridging are completely absent. The colonies formerly known were more vigorous than $\mathrm{J}$. balticus, forming dense stands of up to about $600 \mathrm{~m}^{2}$, and this vigour was retained in cultivation. The Ainsdale and Hightown colonies probably represented different origins, because the stems of the latter were taller and slenderer and the inflorescences less dense, again retained in cultivation. The most reliable ways of distinguishing this hybrid from J. balticus are the intermediate (short-armed stellate) shape of its pith-cells and its high sterility. Wilcox (2011) obtained "some seed" from the transplanted Hightown1973 clone. Chromosome counts of all three wild colonies were $2 \mathrm{n}=80-82$ (J.W. Grimes, J.P. Bailey \& C.A. Stace, unpubl.) (see under J. balticus $x$ J. inflexus for explanation).

\section{J. balticus $\times$ J. filiformis $=$ J. $x$ inundatus (Fig. 13)}

This non-British hybrid resembles J. x obotritorum and J. balticus, from which it can be distinguished by characters derived from J. filiformis. the thinner stems and the smaller, sparser inflorescences which are borne lower down on the stem-bract axis. It does produce a small amount of apparently good seed.

Juncus balticus $\mathrm{x}$ J. inflexus (Figs. $13 \& 14$ )

Juncus balticus $\mathrm{x} J$. inflexus has been discovered in three sites in Lancashire, where it is endemic. Probably all are single clones, one of them now extending over 1000 $\mathrm{m}^{2}$.

\section{Morphology and anatomy}

This hybrid rush is very distinctive among all British Juncus in its extreme vigour, at least in the two Sefton colonies, making it easily our largest Juncus taxon. The stems regularly attain $1.5 \mathrm{~m}$, and occasionally $2 \mathrm{~m}$, in height (Fig. 10). Rhizome growth is also notable; one transplant of the Birkdale colony in the Ainsdale N.N.R. increased in area from $14 \mathrm{~m}^{2}$ in 2003 to $804 \mathrm{~m}^{2}$ in 2015 , an increase of $5743 \%$ in 12 years (Smith \& Lockwood, 2016). Measured on site, rhizomes were found to grow about $0.5 \mathrm{~m}$ per year, i.e. a patch would increase in diameter by about $1 \mathrm{~m}$ (Stace, unpubl.). The internode length in the rhizomes, however, seems no greater than in J. balticus (Fig. 4). These features render the two Sefton colonies instantly recognizable. They agree with $\mathrm{J}$. $\mathrm{x}$ obotritorum in completely lacking subepidermal sclerenchyma girders, and in having intermediate (short-armed stellate) shaped pithcells (Fig. 14). However, the enlarged epidermal cells overlying what would have been the position of subepidermal girders, marked in this hybrid by the position of the larger deeper-seated vascular bundles, are usually clearly developed, so much so that they often form very low albeit visible external stem-ridges. The pith is distinctly interrupted, but not as regularly septate as in J. inflexus. The inflorescence has longer branches (up to $14.5 \mathrm{~cm}$ ) and is more diffuse than in any species or other hybrid of section Juncotypus, all the branches are upswept as in J. inflexus. 


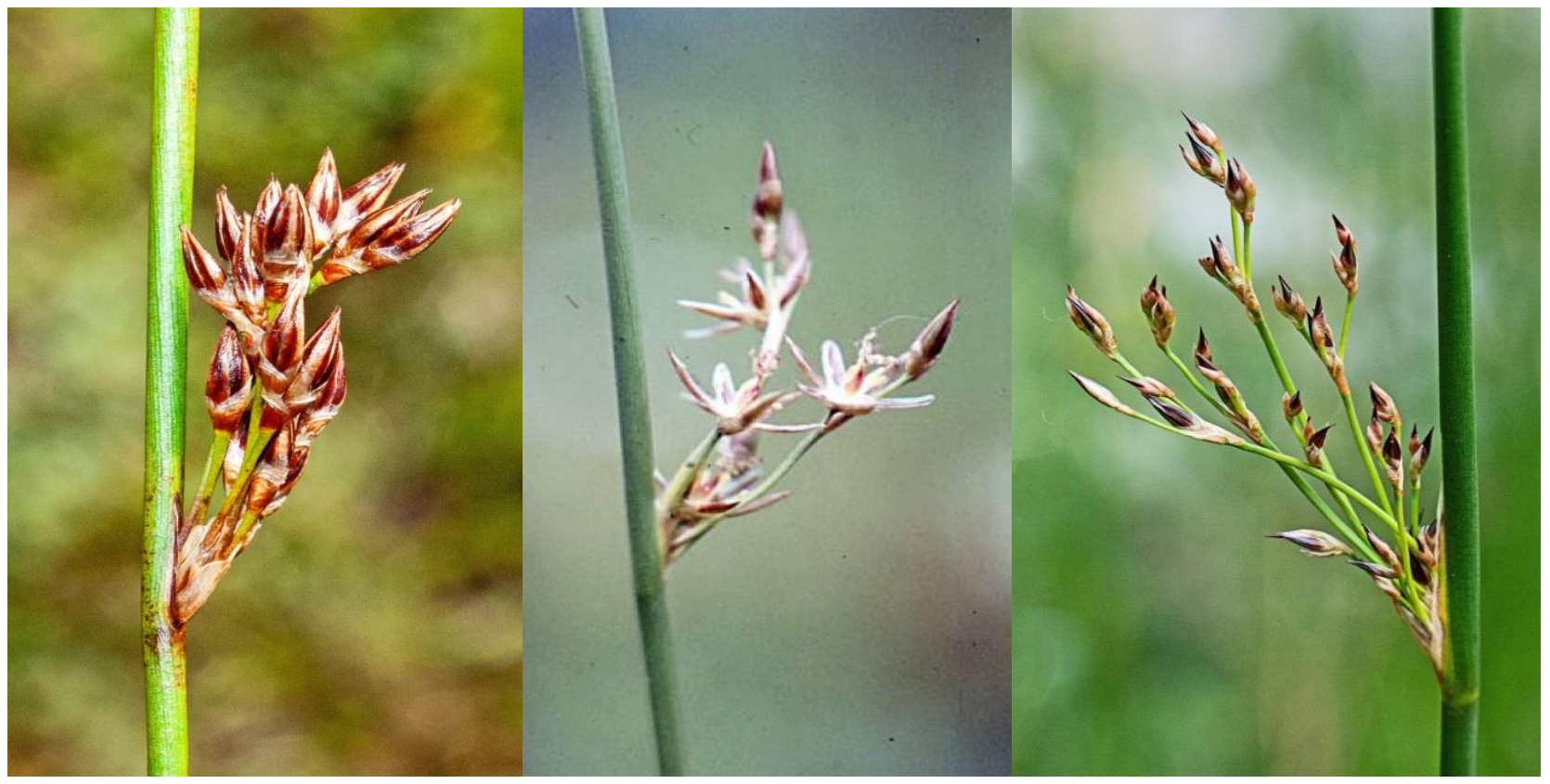

Figure 13. Inflorescences of Juncus $x$ obotritorum (left, Phil Smith), Juncus $x$ inundatus (centre), and Juncus $x$ lancastriensis (right, Phil Smith)

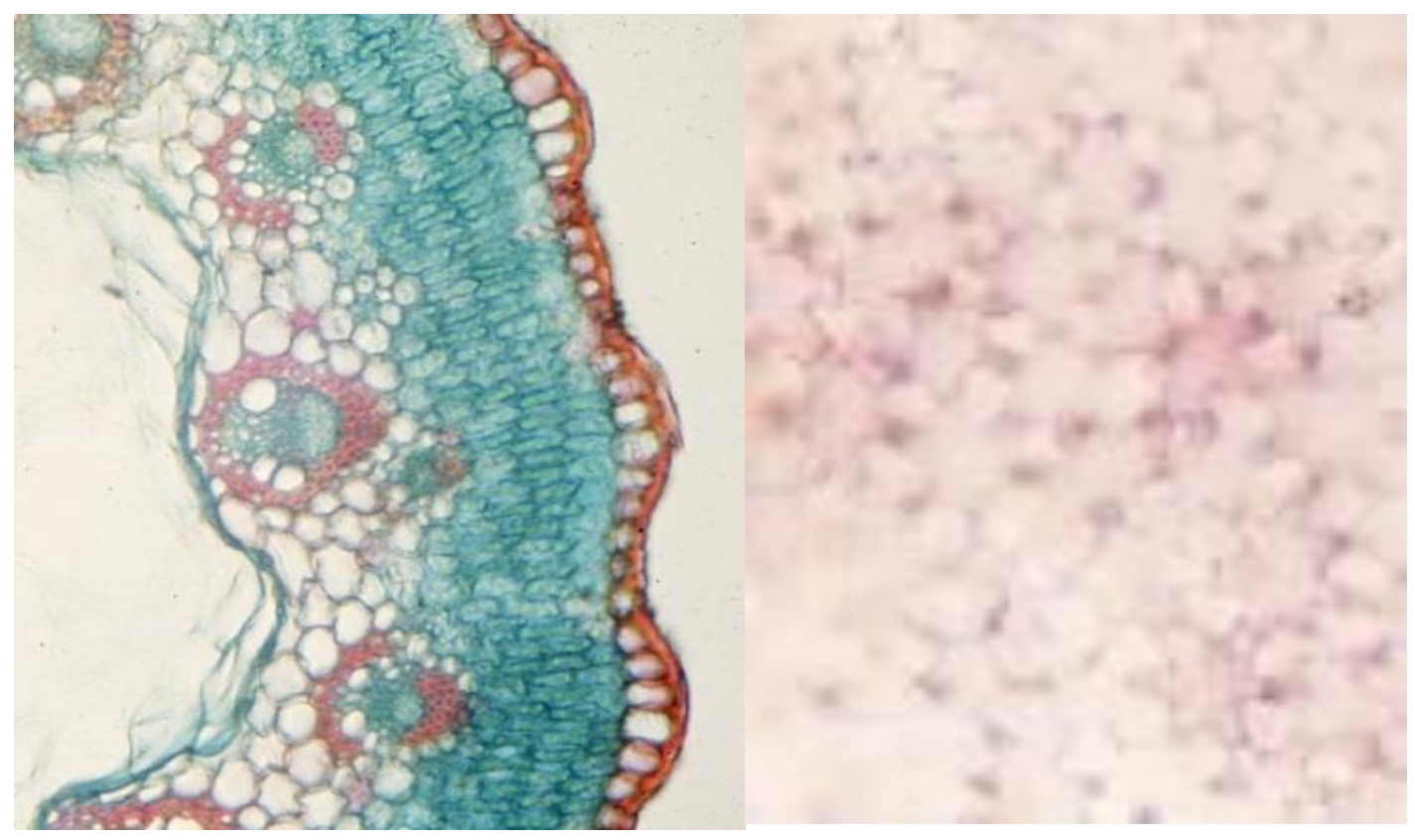

Figure 14. Stem anatomy of Juncus $x$ lancastriensis. Left: stem section showing absence of subepidermal sclerenchyma girders but presence of areas of enlarged epidermal cells; Right: short-armed stellate pith-cells

There is some evidence that the two Sefton colonies are different clones representing different hybridisation events. My colleague J.W. Grimes noticed that it was easier to break off a stem by hand in one of the clones than in the other, a 
feature of both wild and cultivated plants. Sure enough, stem sections showed that there is more sclerenchymatous tissue surrounding the vascular bundles in the tougher clone. The third colony (Fylde) differs considerably from the two Sefton colonies, which (having experience of the latter two) delayed my identification of it until anatomical characters were employed. The Fylde plant is less robust, with shorter, thinner stems closer to $1 \mathrm{~m}$ rather than $1.5 \mathrm{~m}$ tall, although it also has a good rate of rhizome extension. A transplant in the Ainsdale N.N.R. increased in area by $180 \%$ in 12 years (Smith \& Lockwood, 2016). The inflorescence of the Fylde colony is also much shorter (usually $<5 \mathrm{~cm}$ ) than those of the Sefton colonies, and the stems are darker green. The most notable difference, however, is that in the Fylde clone the pith is more or less continuous. Detailed measurements of various characters of the Sefton and Fylde populations were tabulated by Wilcox (2011). It seems very likely that the Fylde colony arose from a different hybridisation event. Soon after the discovery of J. balticus on the Fylde coast by E.S. Marshall in 1914 (Marshall, 1915a), A Bennett (Marshall, 1915b) expressed the opinion that the plants belonged to var. pseudoinundatus Asch. \& Graebn., which differs from the type (represented by the Sefton J. balticus) in its slenderer, greener stems and fewerflowered shorter inflorescences. It seems likely that the difference between the Sefton and Fylde hybrids rests on this different parentage. The epithet pseudoinundatus refers to the fact that the plant resembles the hybrid J. balticus $\mathrm{x} J$. filiformis ( $\mathrm{J} . \mathrm{x}$ inundatus) in general morphology.

\section{Chromosomes}

The chromosomes of Juncus are very small and difficult to study. They are holocentric, i.e. there is no visible constriction or centromere, centromeric activity being dispersed along the chromosome length. This means that chromosome fragments (which commonly arise by mishap in most plants, usually causing death) persist as viable chromosomal components, giving rise to a range of chromosome counts in different plants of one species Hence differences in chromosome number of one or few pairs are probably not very significant. (This phenomenon is even more prevalent in Carex).

The three common species (J. conglomeratus, J. effusus and J. inflexus) have chromosome counts of $2 n=40$ or 42 , while the two rarer species (J. balticus and $J$. filiformis) are usually reported as $2 n=80$ or 84 , although there are a few reports of $2 n=40$ for both. Our own counts (J.W. Grimes, J.P. Bailey \& C.A. Stace., unpubl.) agree with these, being $2 \mathrm{n}=84$ for $\mathrm{J}$. balticus. Our counts for J. balticus $\times \mathrm{J}$. inflexus from all three wild colonies were unexpectedly $2 n=80-84$, indicating either that the $J$. inflexus parent contributed unreduced chromosomes or, less likely, that two pollen grains from the tetrad effected fertilisation. The situation regarding $J$. balticus $\mathrm{x} J$. effusus is similar (see above).

\section{Fertility}

This hybrid, like $J$. balticus $\mathrm{x} J$. effusus, is highly sterile, much more so than $J . x$ diffusus, and seed-bearing capsules are usually hard to find. Nevertheless Wilcox (2011) found capsules containing on average 1-6 seeds in 33 of 2013 flowers $(0.75 \%)$ in the Fylde clone, 41 of $2805(0.57 \%)$ in the transplanted Freshfield clone, and 104 of 2948 (3.53\%) in the Birkdale clone. Wilcox found that the seed harvested could be germinated and he grew some derived from the Birkdale clone to 
maturity. They closely resembled their $F_{1}$ parent and were similarly highly sterile. One plant is still in cultivation.

\section{Hybrid synthesis}

Artificial hybridization is difficult because the flowers are very small, many are borne close together, and the plants are self-fertile. Nevertheless Wilcox managed to synthesise J. conglomeratus $x$ J. inflexus (see above), and my colleague J.W. Grimes achieved the same with $J$. balticus $x \mathrm{~J}$. inflexus, using Freshfield material of $J$. inflexus as the female parent and Birkdale material of J. balticus as male. Only one plant was obtained, but it was grown to maturity (LTR) and found to agree in all details with the wild Sefton hybrids. Interestingly, its chromosome number was $2 n=$ c.62 (J.P. Bailey, unpubl.), indicating that, unlike the case with all the wild hybrids, both parents contributed unreduced gametes.

\section{Hybrid binomial}

All other hybrids in this section have valid binomials and, as the present hybrid still thrives in the wild, one is provided for that here.

Juncus x lancastriensis Stace, nothosp. nov. (J. balticus Willd. x J. inflexus L.) Stems isolated, not clustered, borne on vigorous rhizomes with internodes mostly $\geq 1$ $\mathrm{cm}$ long, commonly $1.5 \mathrm{~m}$ (up to $2 \mathrm{~m}$ ) in height, mid green in colour, without subepidermal sclerenchyma girders, with irregularly longitudinally interrupted pith; pith-cells stellate with short arms; longitudinal rows of epidermal cells enlarged, mostly in clusters overlying the larger vascular bundles; inflorescences very diffuse, with upswept branches $2.5-14.5 \mathrm{~cm}$; tepals pale brown to straw-coloured; highly sterile but some capsules (mostly $<1 \%$ ) have viable seeds.

Inflorescence lengths are from Wilcox (2011). The elongated rhizomes and the tall stems with elongated diffuse inflorescences, lacking sclerenchyma girders and with short-armed stellate pith-cells and zones of enlarged epidermal cells are diagnostic.

Holotype: In extensive dune-slacks among dunes near sea, Ainsdale sand-dunes nature reserve (Freshfield site, Ainsdale N.N.R.), Sefton coast, South Lancashire, v.c.59, Grid reference SD308143, C.A. Stace s.n., September 1970 (LTR). (Fig. 15). Isotypes or topotypes (other collections of the same clone) are in BM, K, LTR and MANCH. A wild-collected sheet is selected as holotype; more fully representative material cultivated in Manchester is present in LTR and MANCH. 


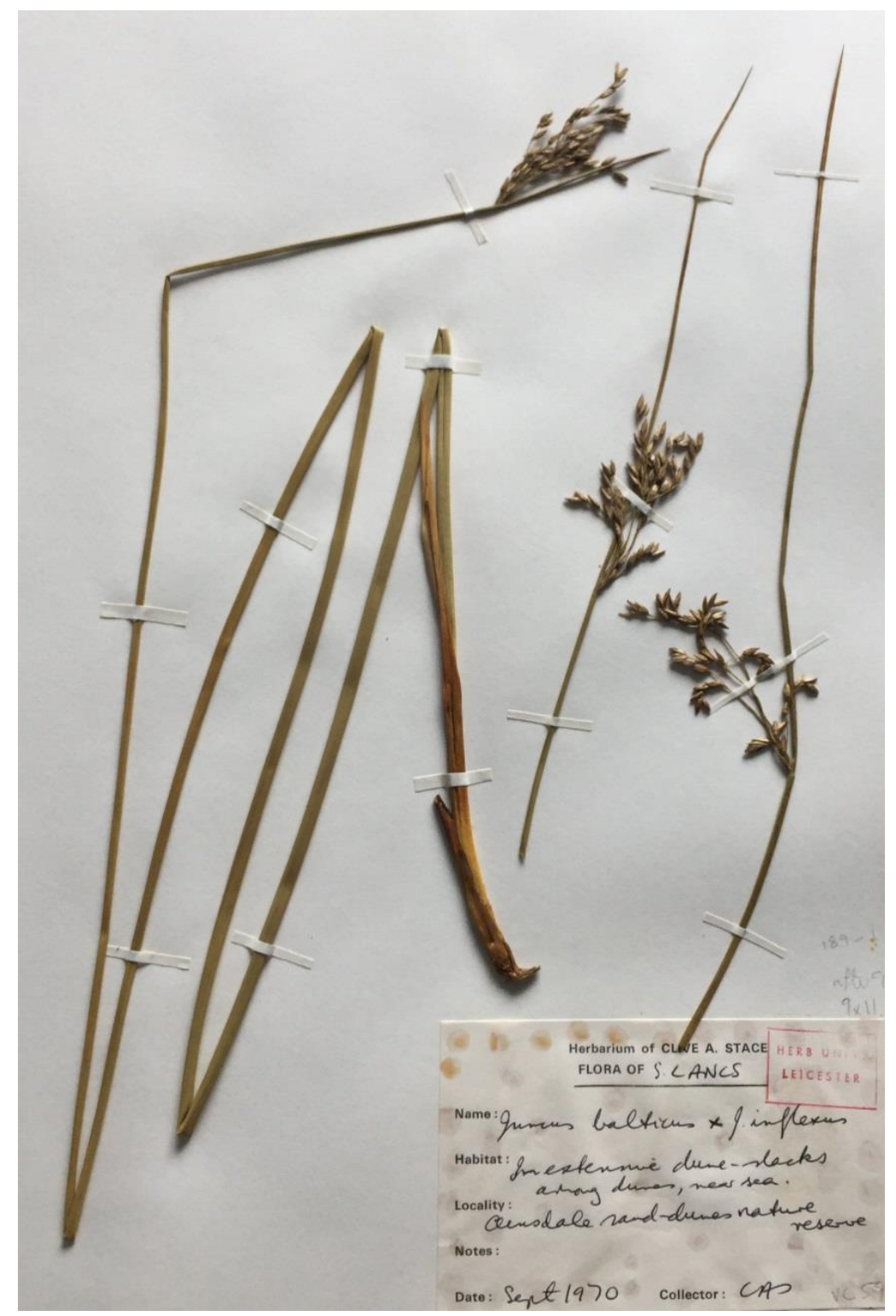

Figure 15. Holotype of Juncus $x$ lancastriensis. Image by Stuart Desjardins

The above material represents nothovar. lancastriensis, its J. balticus parent being referable to var. balticus. The clone on the Fylde coast differs substantially from this, and deserves naming as a distinct nothovar.

Juncus $\mathbf{x}$ lancastriensis Stace nothovar. fyldensis Stace, nothovar. nov. ( $J$. balticus var. pseudoinundatus Asch. \& Graebn. $x$ J. inflexus)

Differs from nothovar. lancastriensis in: shorter stems (mostly c.1 m, up to $1.35 \mathrm{~m}$ ) darker green in colour; less elongated inflorescences $(1.3-5.5 \mathrm{~cm})$; more darkly pigmented tepals; and stems with non-interrupted pith.

Holotype: Dune-slack, Fylde coast between Lytham and Blackpool (Lytham St Anne's Local Nature Reserve, Starr Hills), West Lancashire, v.c.60, Grid reference SD311303, C.A. Stace S.n., July 1966 (LTR) (Fig. 16). 


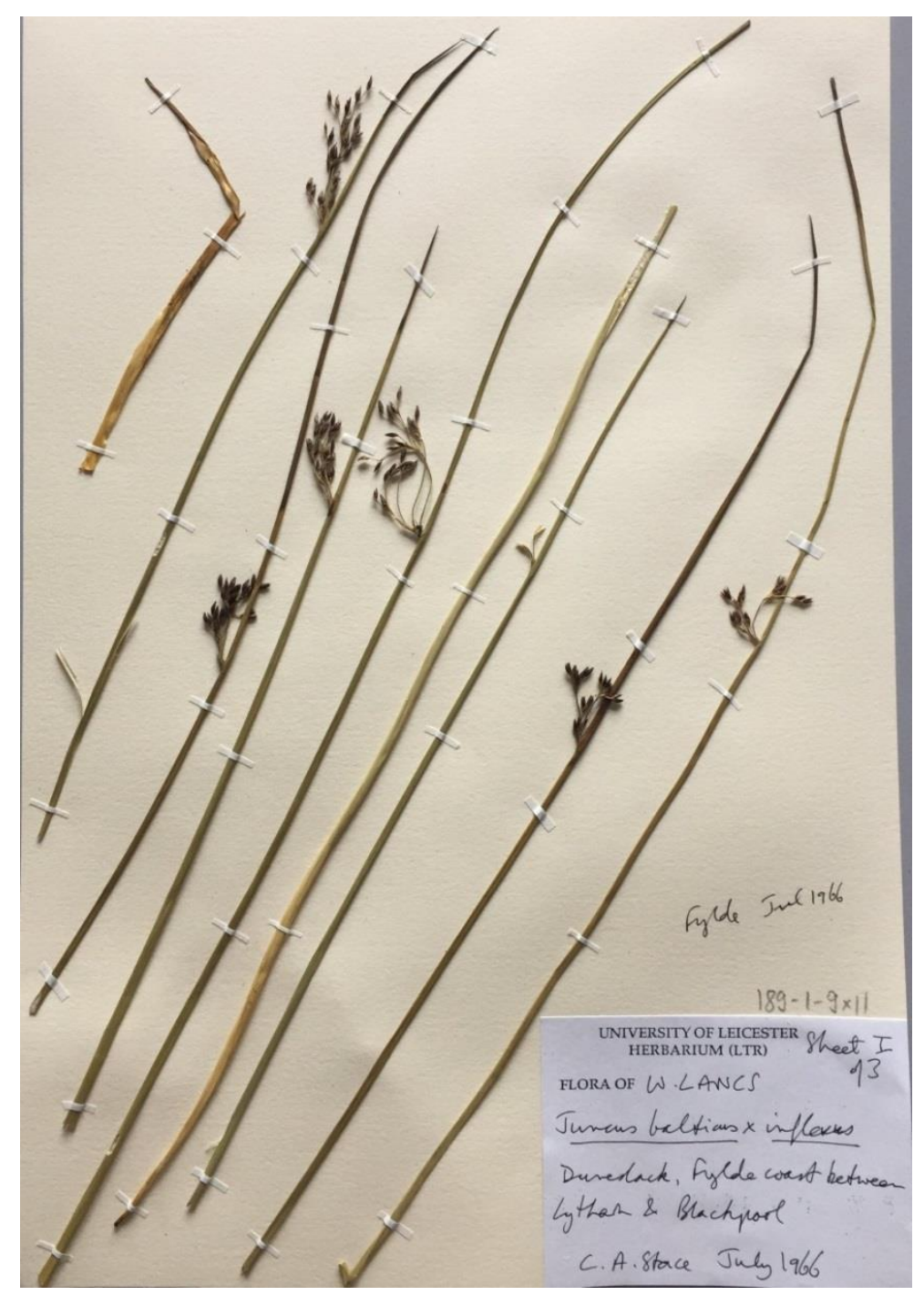

Figure 16. Holotype of Juncus $x$ lancastriensis nothovar. fyldensis. Image by Stuart Desjardins

A specimen collected in 1968 is in MANCH.

\section{Acknowledgements}

I am very grateful to the following for helping in a great variety of ways: J.P. Bailey (especially for chromosome counts), S. Desjardins, V. Gordon, E.F. Greenwood, J.W. Grimes (a colleague for three years who did most of the investigations in the period 1971-1973), P.W. Richards, P.H. Smith (who provided local information and kindly gave me permission to publish some of his photographs), S. Snogerup, R.C. Stace (for photographs), S.M. Walters and Rachel Webster (for information on specimens in MANCH), and in particular to M.P. Wilcox, who kindly made much information freely available to me, provided several photographs, and commented on a draft of this paper.

\section{References}

Agnew, A.D.Q. 1968. The interspecific relationships of Juncus effusus and J. conglomeratus in Britain. Watsonia 6: 377-388. 
Clifford, H.T. 1959. On putative hybrids between Juncus inflexus L. and Juncus effusus L. Kew Bulletin 13: 392-395.

Marshall, E.S. 1915a. Juncus balticus Willd. in W. Lancs. The Journal of Botany, British and Foreign 53: 91.

Marshall, E.S. 1915b. Juncus balticus Willd. The Journal of Botany, British and Foreign 53: 147-148.

Preston, C.D., Pearman, D.A. \& Dines, T.D. 2002. New Atlas of the British and Irish Flora, p. 696. Oxford: Oxford University Press.

Richards, P.W. 1962. Juncus L., pp. 984-994. In: Clapham, A.R., Tutin, T.G. \& Warburg, E.F. Flora of the British Isles, $2^{\text {nd }}$. ed. Cambridge: Cambridge University Press.

Smith, P.H. 1984. The distribution, status and conservation of Juncus balticus Willd. in England. Watsonia, 15: 15-26. http://archive.bsbi.org.uk/Wats15p15.pdf

Smith, P.H. 2006. Revisiting Juncus balticus Willd. in England. Watsonia, 26: 57-65. http://archive.bsbi.org.uk/Wats26p57.pdf

Smith, P.H. \& Lockwood, P.A. 2016. Status of Juncus balticus (Baltic Rush) and its hybrids in England. BSBI News 131: 8-16.

Stace, C.A. 1970a. Anatomy and taxonomy in Juncus subgenus Genuini, pp. 75-81. In: Robson, N.K.B., Cutler, D.F. \& Gregory, M., eds, New Research in Plant Anatomy. London: Academic Press.

Stace, C.A. 1970b. Unique Juncus hybrids in Lancashire. Nature, London 226: 180.

Stace, C.A. 1972. The history and occurrence in Britain of hybrids in Juncus subgenus Genuini. Watsonia 9: 1-11. http://archive.bsbi.org.uk/Wats9p1.pdf

Stace, C.A. 1975a. Juncus L., pp. 461-467. In: Stace, C.A., ed., Hybridization and the Flora of the British Isles. London: Academic Press.

Stace, C.A. 1975b. Wild hybrids in the British flora, pp. 111-125. In: Walters, S.M. \& King, C.J., eds, European Floristic and Taxonomic Studies. Faringdon: E.W. Classey Ltd.

Stace, C.A., Preston, C.D. \& Pearman, D.A. 2015. Hybrid Flora of the British Isles, pp. 372-376. Bristol: Botanical Society of Britain \& Ireland.

Stace, C.A. 2019. New Flora of the British Isles, $4^{\text {th }}$ ed., pp. 974-986. Middlewood Green, Suffolk: C \& M Floristics.

Wilcox, M.P. 2010. A novel approach to the determination and identification of Juncus x diffusus Hoppe and J. x kern-reichgeltii Jansen \& Wacht. ex Reichg. Watsonia 28: 43-56. http://archive.bsbi.org.uk/Wats28p43.pdf

Wilcox, M.P. 2011. Hybrid rushes in the U.K. - sterility and fertility. BSBI News 116: 21-27.

Wilcox, M.P. 2015. Juncus inflexus $x$ J. conglomeratus. BSBI News 130: 31. Wilcox, M.P. 2017. Juncus inflexus x J. conglomeratus - Postscript. BSBI News 135: 40.

Copyright retained by author(s). Published by BSBI under the terms of the Creative Commons Attribution 4.0 International Public License.

ISSN: $2632-4970$

https://doi.org/10.33928/bib.2020.02.266 